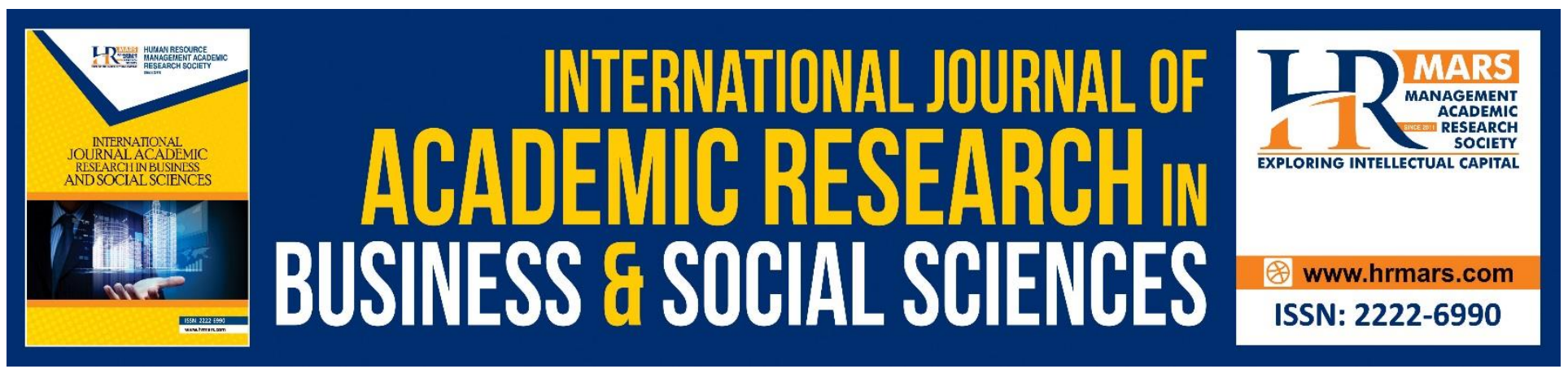

\title{
Effects of Big Five Personality Traits on Job Crafting among Private University Academic Staff
}

\section{Tan Chi Hau, Khuan Wai Bing, Bhargkavi A/P Pari}

To Link this Article: http://dx.doi.org/10.6007/IJARBSS/v10-i7/7476

DOI:10.6007/IJARBSS/v10-i7/7476

Received: 07 April 2020, Revised: 11 May 2020, Accepted: 18 June 2020

Published Online: 08 July 2020

In-Text Citation: (Hau, Bing, Pari, 2020)

To Cite this Article: Hau, T. C., Bing, K. W., Pari, B. A/P. (2020). Effects of Big Five Personality Traits on Job Crafting among Private University Academic Staff. International Journal of Academic Research in Business and Social sciences. 10(7), 607-620.

\section{Copyright: (C) 2020 The Author(s)}

Published by Human Resource Management Academic Research Society (www.hrmars.com)

This article is published under the Creative Commons Attribution (CC BY 4.0) license. Anyone may reproduce, distribute, translate and create derivative works of this article (for both commercial and non-commercial purposes), subject to full attribution to the original publication and authors. The full terms of this license may be seen

at: http://creativecommons.org/licences/by/4.0/legalcode

\section{Vol. 10, No. 7, 2020, Pg. 607 - 620}




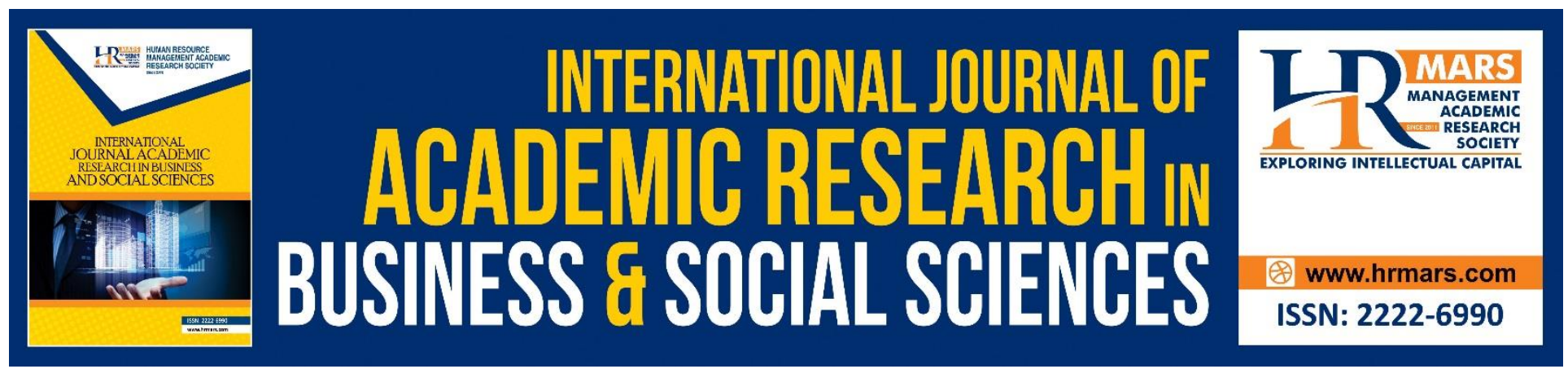

\title{
Effects of Big Five Personality Traits on Job Crafting among Private University Academic Staff
}

\author{
Tan Chi Hau \\ Faculty of Management and Economics, Universiti Pendidikan Sultan Idris, Centre for Foundation \\ Studies, Universiti Tunku Abdul Rahman \\ Email: hau0314@hotmail.com
}

Khuan Wai Bing

Faculty of Management and Economics, Universiti Pendidikan Sultan Idris

Bhargkavi A/P Pari

Centre for Foundation Studies, Universiti Tunku Abdul Rahman

\begin{abstract}
The objective of this study is to examine the effects of Big Five personality traits on job crafting among private university academic staff. A total of 284 completed surveys were collected using a proportionate stratified sampling method and a simple random sampling technique. Applying the use of Partial Least Square-Structural Equation Modelling, the results have shown that agreeableness ( $\beta$ $=0.257, p<0.05)$, openness to experience $(\beta=0.195, p<0.05)$, and extraversion $(\beta=0.349, p<0.05)$ promote job crafting behaviour. Theoretically, a comprehensive conceptual model for the Big Five personality traits and job crafting has been developed, and serves as a valuable reference for future studies. Moreover, this study also provides limitations and recommendations for future research.

Keywords: Big Five Personality Traits, Job Crafting, Private University and Academic Staff.
\end{abstract}

\section{Introduction}

Education is instrumental to an individual's success. Education enables a person to acquire the necessary skills that will prepare them for every mental, social and physical life aspect. These skills are communication skills, teamwork skills, problem solving skills, adaptive thinking and soft skills (Kamarudin et al., 2012; Sung, Chang \& Liu, 2016). Moreover, these skills are useful when one is entering the work field. Social opulence, political stability and economic wealth are all made feasible through education and contribution by social members such as academicians (Da Wan, Sirat \& Razak, 2015; Musa \& Abd Halim, 2015). Academic staff is an essential element for every educational institution especially among private Higher Education Institutions (HEls) in the competitive market. Higher proactive behaviour among the academic staff results in impressive performance that will 
bring about a healthier and more positive climate in the institution (Noordin \& Jusoff, 2009; Andersson \& Pears, 2017).

Often, each academic staff possesses personality traits that can distinguish his or her behaviour from the others. In other words, different academic staff portrays different types of internal characteristics. These traits will render them to be either more or less suited with the changes of the learning or teaching environment. The Big Five personality traits are one of the best personality measurement tools and is the most highly regarded trait theories of personality (Digman, 1990; Wiggins \& Trapnell, 1997; Harari, Jain \& Joseph, 2014). This theory includes five personality dimensions which are extraversion, conscientiousness, agreeableness, neuroticism and openness to experience (Ono, Sachau, Deal, Englert \& Taylor, 2011).

The 'Learn to teach' approach has always been adopted by an effective academic staff in order to improve the art and quality of teaching (Lai \& Hamdam, 2014). In addition, in the digital world, economic changes and technological advances in the field of education force organisations and their people to constantly adapt (Zhu, Sun \& Riezebos, 2016; van Wingerden, Bakker \& Derks, 2017). For instance, in the higher educational landscape, academic staffs can no longer just use their whiteboard and power point slides but have to utilise educational technologies such as a learning software, online learning as well as mobile learning. For this reason, the employee's jobs are directly affected by forces that are from outside of the organisations. As a result, the employees may need to change their task size and processes to fit between the recent movement in education trends and their personal situation in order to stay engage in the workplace. These proactive self-initiated job changes are called job crafting (Wrzesniewski \& Dutton, 2001).

Job crafting is explained as a process where employees make any physical, cognitive and social elements changes in their jobs and relationships with others to redefine the meaning of their work (Wrzesniewski \& Dutton, 2001). Job crafting can also be defined as a persuasive instrument to reenergise work life where it involves redefining the job to incorporate employee's purposes, strengths, and passions (Wrzesniewski, LoBuglio, Dutton \& Berg, 2013). Job crafting can be divided into a few techniques, first, employees may adjust task-related aspects of their jobs, such as the amount or the content of the tasks that they have; second, employees may change the relationship aspects of their jobs, for example the depth of connection with co-workers or customers; and finally, employees may change their thoughts about their jobs to boost the meaning of their work (Tims, Bakker \& Derks, 2012).

Job crafting is significantly linked to the Big Five personality traits. Accordingly, job crafting has been practised locally and internationally in various groups of occupations including school teachers, doctors, hospital nurses, dentists, blue-collar and white-collar workers (e.g. engineers, human resource executives and administrative staffs) and private home-care professionals (Janse van Rensburg, Boonzaier \& Boonzaier, 2013). Yet, few job crafting have been carried out among private university academic staffs in Malaysia. Hence, there is a need to study the personality types that are most likely to craft academic jobs in order to ensure continuous high job performance in private HEls within the Malaysian context.

\section{Research Objective}

The general objective of this study is: 
INTERNATIONAL JOURNAL OF ACADEMIC RESEARCH IN BUSINESS AND SOCIAL SCIENCES

Vol. 10, No. 7, July, 2020, E-ISSN: 2222-6990 @ 2020 HRMARS

- To examine the effects of Big Five personality traits (openness to experience, conscientiousness, agreeableness, neuroticism \& extraversion) on job crafting among private university academic staff.

\section{Literature Review}

There is a shortage of previous research that has linked the Big Five personality traits and job crafting in the context of private higher education institutions. However, the exploratory study that has been conducted by Lyons (2008) have found that the readiness to change positively affects job crafting behaviour. Moreover, Tims et al. (2012) and Bakker, Tims and Derks (2012) have shown that employees who have a tendency to initiate change and who are open to new experience are more likely to engage in both tasks (e.g. seeking new task) and relational (e.g. minimise contact with unrealistic people) forms of job crafting. In another related study, by using multiple regression analysis Bell's and Njoli's (2016) study has shown that openness to experience has a statistically and practically significant role on predicting job crafting behaviours among 246 administrative employees in a tertiary institution environment. Thus,

H1. Openness to experience has a significant effect on job crafting.

Chiaburu, Oh, Berry, Li and Gardner (2011) have mentioned that an employee with a high score on conscientiousness likes order and tends to follow rules. The employee is less likely to change the tasks or job characteristics (Bell \& Murugan, 2013). Similar result is also observed in the study of Schaufeli (2013) and Tims, Bakkers and Derks (2013) who have found that conscientious employees have lesser tendencies to be involved in job crafting, as these employees are less likely to reduce the level of job demands or to increase the level of job resources or both, but will still be highly engaged in their job performance. On the contrary, a recent study by Morton, Hill and Meiring (2018) have reported that conscientiousness predicts job crafting. These inconsistent findings highlight the need to further explore the association between conscientiousness and job crafting behaviours. In terms of agreeableness, it appears that agreeableness does not predict job performance very well (Barrick, Mount \& Judge, 2001) but is related to job crafting (Peral \& Geldenhuys, 2020). This employee is eager to help others, is cooperative, modest, caring, kind and desires to maintain a good relationship with others (Ilies, Fulmer, Spitzmuller \& Johnson, 2009; Mehmetoglu, 2012). As a result, they are more likely to shape their job in order to giving support to others' plans and interests, and also to increase the quantity and quality of their interactions with others (Hogan \& Holland, 2003; Chiaburu et al., 2011; Barrick, Mount \& Li, 2013). Thus,

H2. Conscientiousness has a significant effect on job crafting.

H3. Agreeableness has a significant effect on job crafting.

Neuroticism is associated with emotional instability, difficulties in calming down, over activity, emotionally over responsive and has a negative effect (Eysenck \& Eysenck, 1994; Costa \& McCrea, 1995). These employees have high level of stress proneness and they view their work environment as threatening, which results in reduced job performance and causes negative emotions such as depression (Schneider, 2004). Marta and Bakker (2016) have demonstrated that neuroticism has a negative significant effect on job crafting, in particular, neuroticism has negative relationships with increasing job resources and challenging demands, and positive relationships with decreasing hindering job demands. Similarly, using Structural Equation Modelling (SEM) analysis, neuroticism has proven to be negatively correlated with increasing structural job resources and challenging job 
INTERNATIONAL JOURNAL OF ACADEMIC RESEARCH IN BUSINESS AND SOCIAL SCIENCES Vol. 10, No. 7, July, 2020, E-ISSN: 2222-6990 @ 2020 HRMARS

demands (Chinelato, Ferreira \& Valentini, 2015). Not surprisingly, neuroticism is negatively related to high levels of task demands (job crafting behaviour) (Sterns, Alexander, Barrett \& Dambrot, 1983). Thus,

H4. Neuroticism has a significant effect on job crafting.

Finally, research has shown that extraverted employees have greater energetic behavioural tendency towards the world (Bono \& Judge, 2004) and are more effective in group work, probably because they tend to seek new attention, ask more questions (Barrick et al., 2001) and indicate more social contact during daily activities (Oerlemans \& Bakkers, 2014). A recent study by Morton et al., (2018) has proven that extraversion is found to be significantly related to decreasing hindering job demands $(\beta=0.20)$ and increasing social job resources $(\beta=0.18)$ among 313 workers from various industries in South Africa, using the SEM. Furthermore, Marta's and Bakker's (2016) study of 155 individuals in various occupations has revealed that extraversion is found to be a significant positive predictor of increasing structural and social job resources, and the seeking of challenging job demands. At the same time, Bell and Njoli (2016) have also predicted that employees who are high in extraversion are more likely to engage in job crafting in situations when they are not satisfied with their interpersonal competences and needs. Thus,

H5. Extraversion has a significant effect on job crafting.

\section{Conceptual Framework}

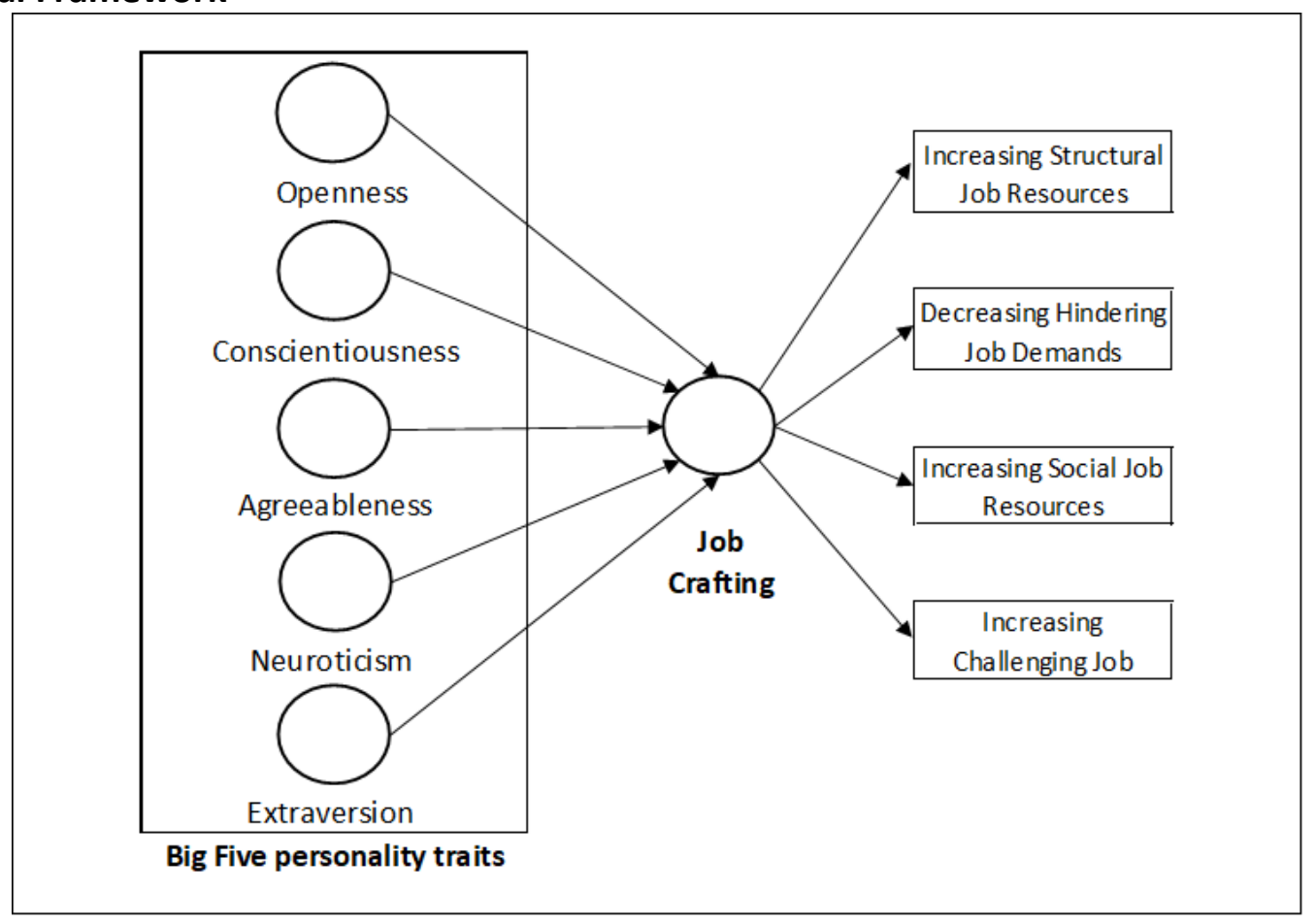

Figure I: Framework

\section{Methodology}

\section{Research Participants}

The survey has been participated by academic staffs from two private universities that are located in Perak state, Malaysia. The total number of academic staffs from both of the private universities who 
were involved in this study were 284. Approximately 27.1 percent of the academic staffs were males and 72.9 percent were females. Moreover, a majority of the academic staffs were in the age group of between 30 to less than 40 years old (38.4 percent), and was followed closely by the academic staffs from the age group of less than 30 years old (32.4 percent). In terms of educational level, the results revealed that a majority of the academic staffs had earned a Master's degree (44.4 percent) and also a doctorate degree (29.5 percent). With regards to the number of years in a teaching field, a majority of the respondents had served as an academic staff for 3 to less than 5 years ( 63.0 percent). Lastly, a majority of the academic staffs were lecturers (58.8 percent), followed by assistant professors (22.9 percent).

\section{Sampling Design}

A proportionate stratified sampling method together with the simple random sampling technique were used in this study. Probability sampling was adopted to minimise the random sampling error and to provide better generalisability (Zikmund, Babin, Carr \& Griffin, 2010). To use proportionate stratified sampling, a list of academic staff was gathered from the university staff directory. Shortlisting of proportionate stratified sampling was based on position such as a lecturer, senior lecturer, principal lecturer, assistant lecturer, associate professor, professor and senior professor where each position group represented a stratum. About 1,712 academic staffs were regarded as qualified to take part in the study. Out of the total listing from the university staff directory, a total of 500 questionnaires were distributed to the academic staffs.

\section{Questionnaire Design}

The research approach that has been used in this study is a self-administered questionnaire. Questionnaires were sent through email and the link was attached to the questionnaires. The reason in using the self-administered questionnaire was because of its geographical flexibility as well as the lower distribution and processing costs (Zhang, Lars, Marcella, Julia \& Jurgen, 2017). Basically, the 46 items questionnaire were divided into Section $A, B$ and $C$. Section $A$ was closed-ended questions while $B$ and $C$ were scale-response questions.

Section A consisted of demographic information where the respondents were required to fill in their personal information. Both section B and section C used a five-point Likert scale and consisted of questions on the Big Five personality traits and job crafting, respectively. A Big Five personality trait was assessed using the Mini International Personality Item Pool (Mini-IPIP) by Donnellan, Oswald, Baird and Lucas (2006). The continuous scale had a total of 20 questions that covered five personality traits. Upon development of the instrument, Donnellan et al., (2006) had found that the Cronbach's alpha coefficients for extraversion, conscientiousness, openness to experience, neuroticism and agreeableness to be $0.82,0.75,0.70,0.70$ and 0.75 , respectively. The job crafting scale (JCS), developed by Tims et al. (2012) was used to assess job crafting behaviour among the respondents. The continuous scale consisted of 21 questions that covered four dimensions. Tims et al. (2012) found that the Cronbach's alpha to be over 0.70 for all dimensions.

\section{Data Analysis}

Partial Least Square-Structural Equation Modelling (PLS-SEM) was used to examine the relationship between the Big Five personality traits and job crafting. The evaluation of PLS-SEM had included a two-stage process. Stage one included internal consistency, indicator reliability, convergent validity 
and discriminant validity, which were tested on the reflective model. The test began with internal consistency through examination on the composite reliability. Hair, Hult, Ringle and Sarstedt (2017) had stated that the value of 0.60 to 0.70 was deemed acceptable in exploratory study while the value of 0.70 to 0.90 was considered as satisfactory. The next step involved indicator reliability which was done by examining the indicator loadings. Based on the rule of thumb, the factor loadings which exceeded 0.7 would be deemed acceptable (Sarstedt, Ringle, Smith, Reams \& Hair, 2014). Thereon, the study continued with the assessment of the convergent validity. The average variance extracted (AVE) was used to evaluate the convergent validity. Generally, an AVE of 0.50 and higher would be deemed acceptable. The last step was to evaluate the discriminant validity of the constructs. Discriminant validity was assessed through Fornell's and Lacker's (1981) criterion. The square root of AVE of a construct should be greater than the correlations between the construct and other constructs in the model (Hair, Ringle \& Sarstedt, 2011).

In stage two, the structural model assessment was conducted. The key criteria for assessing the structural model in PLS-SEM would be the significance of the path coefficients and the level of $R^{2}$ value. The path coefficient values were standardised based on a range from -1 to +1 . Coefficients closer to +1 would indicate a strong positive relationship whereas coefficients closer to -1 would represent strong negative relationships. Moreover, Hair et al. (2017) had stated that $R^{2}$ values of 0.75 , 0.50 and 0.25 may be considered substantial, moderate and weak, respectively.

\section{Measurement Model}

Figure I shows that job crafting is conceptualised as second-order constructs. Thus, the study followed the method that was suggested in the literature in PLS which was the repeated indicator approach in order to model the second-order construct in the PLS analysis. Table I shows that the results of the measurement model have exceeded the recommended values, thus indicating a satisfactory internal consistency reliability and sufficient convergence validity. 
INTERNATIONAL JOURNAL OF ACADEMIC RESEARCH IN BUSINESS AND SOCIAL SCIENCES

Vol. 10, No. 7, July, 2020, E-ISSN: 2222-6990 @ 2020 HRMARS

Table I: Measurement Model

\begin{tabular}{|c|c|c|c|c|c|}
\hline First-order constructs & $\begin{array}{c}\text { Second-order } \\
\text { construct }\end{array}$ & Items & Loadings & $\begin{array}{l}\text { Composite } \\
\text { Reliability }\end{array}$ & AVE \\
\hline Openness to Experience & & 01 & 0.731 & 0.782 & 0.644 \\
\hline \multirow[t]{2}{*}{ (0) } & & $\mathrm{O} 3$ & 0.835 & & \\
\hline & & $\mathrm{O} 4$ & 0.849 & & \\
\hline \multirow[t]{4}{*}{ Conscientiousness (C) } & & $\mathrm{C} 1$ & 0.885 & 0.898 & 0.746 \\
\hline & & $\mathrm{C} 2$ & 0.897 & & \\
\hline & & C3 & 0.884 & & \\
\hline & & C4 & 0.748 & & \\
\hline \multirow[t]{3}{*}{ Agreeableness (A) } & & A1 & 0.893 & 0.903 & 0.823 \\
\hline & & $\mathrm{A} 2$ & 0.739 & & \\
\hline & & A3 & 0.821 & & \\
\hline \multirow[t]{3}{*}{ Neuroticism (N) } & & N2 & 0.943 & 0.880 & 0.786 \\
\hline & & N3 & 0.827 & & \\
\hline & & N4 & 0.804 & & \\
\hline \multirow[t]{8}{*}{ Extraversion (E) } & & E1 & 0.787 & 0.868 & 0.687 \\
\hline & & E2 & 0.764 & & \\
\hline & & E3 & 0.806 & & \\
\hline & & E4 & 0.715 & & \\
\hline & $\begin{array}{l}\text { Job crafting } \\
\text { (JC) }\end{array}$ & $\begin{array}{l}\text { Increasing Structural } \\
\text { Job Resources }\end{array}$ & 0.733 & 0.900 & 0.540 \\
\hline & & $\begin{array}{l}\text { Decreasing Hindering } \\
\text { Job Demands }\end{array}$ & 0.790 & & \\
\hline & & $\begin{array}{c}\text { Increasing Social Job } \\
\text { Resources }\end{array}$ & 0.745 & & \\
\hline & & $\begin{array}{l}\text { Increasing Challenging } \\
\text { Job Demands }\end{array}$ & 0.791 & & \\
\hline Increasing Structural & & ISJR1 & 0.735 & 0.756 & 0.611 \\
\hline \multirow[t]{3}{*}{ Job Resources } & & ISJR2 & 0.874 & & \\
\hline & & ISJR3 & 0.722 & & \\
\hline & & ISJR4 & 0.899 & & \\
\hline Decreasing Hindering & & DHJD1 & 0.819 & 0.914 & 0.779 \\
\hline \multirow[t]{4}{*}{ Job Demands } & & DHJD2 & 0.797 & & \\
\hline & & DHJD4 & 0.888 & & \\
\hline & & DHJD5 & 0.891 & & \\
\hline & & DHJD6 & 0.813 & & \\
\hline Increasing Social Job & & ISJ1 & 0.771 & 0.823 & 0.801 \\
\hline \multirow[t]{2}{*}{ Resources } & & ISJ3 & 0.856 & & \\
\hline & & ISJ5 & 0.815 & & \\
\hline Increasing Challenging & & ICJD1 & 0.995 & 0.841 & 0.666 \\
\hline \multirow[t]{3}{*}{ Job Demands } & & ICJD3 & 0.903 & & \\
\hline & & ICJD4 & 0.804 & & \\
\hline & & ICJD5 & 0.778 & & \\
\hline
\end{tabular}

After confirming the convergent validity, the study proceeded to assess the discriminant validity using the Fornell and Larcker (1981) method. As illustrated in Table II, the square root of AVE on the 
INTERNATIONAL JOURNAL OF ACADEMIC RESEARCH IN BUSINESS AND SOCIAL SCIENCES

Vol. 10, No. 7, July, 2020, E-ISSN: 2222-6990 @ 2020 HRMARS

diagonal elements shows a higher value than the off-diagonal elements; therefore, acceptable discriminant validity is exhibited.

Table II: Discriminant validity

\begin{tabular}{ccccccc}
\hline Constructs & A & C & E & JC & N & O \\
\hline A & $\mathbf{0 . 8 1 9}$ & & & & & \\
C & -0.002 & $\mathbf{0 . 8 8 9}$ & & & & \\
E & 0.397 & 0.098 & $\mathbf{0 . 5 9 6}$ & & & \\
JC & 0.175 & 0.142 & 0.384 & $\mathbf{0 . 7 0 1}$ & & \\
N & -0.466 & -0.474 & -0.195 & -0.024 & $\mathbf{0 . 8 8 6}$ & \\
$\mathbf{0}$ & -0.030 & 0.554 & 0.327 & 0.176 & -0.293 & $\mathbf{0 . 7 9 2}$ \\
\hline
\end{tabular}

\section{Structural Model}

To evaluate the structural models' predictive power, $R^{2}$ was calculated. $R^{2}$ indicated the amount of variance explained by the exogenous variables (Barclay, Higgins \& Thompson, 1995). All five variables together explained 45.3 per cent of the variance. Using a bootstrapping technique with a re-sampling of 500, the path coefficient and t-statistics were calculated for the hypothesised relationships. Table III revealed the significance of the path coefficient for the hypotheses in the present research. All direct relationships are significant with t-statistic above 1.96 and significant at $p<0.05$ except for hypothesis $\mathrm{H} 2$ and $\mathrm{H} 4$. Results show that extraversion, agreeableness and openness to experience contribute to job crafting significantly with original sample (beta) $=0.349$ for extraversion, beta $=$ 0.257 for agreeableness, and beta $=0.195$ for openness for experience. Extraversion has a positive effect on job crafting with t-statistic $=5.685$ at $p<0.05$. Agreeableness demonstrates a positive effect on job crafting with $t$-statistic $=4.394$ at $p<0.05$. Openness to experience has a positive effect on work engagement with t-statistic $=3.825$ at $p<0.05$. Conscientiousness $(\mathrm{H} 2$ : t-statistic $=0.027$ at $p>$ $0.05)$ and neuroticism ( $\mathrm{H} 4$ : $\mathrm{t}$-statistic $=1.329$ at $\mathrm{p}>0.05)$ however are not supported.

Table III: Hypothesis testing

\begin{tabular}{cccccc}
\hline Hypothesis & $\begin{array}{c}\text { Original } \\
\text { Sample }(\boldsymbol{\beta})\end{array}$ & $\begin{array}{c}\text { Standard } \\
\text { Deviation }\end{array}$ & t-statistic & p-value & Results \\
\hline H1: O $\rightarrow$ JC & 0.195 & 0.051 & 3.825 & $0.000^{*}$ & Supported \\
H2: $\rightarrow$ JC & 0.001 & 0.051 & 0.027 & 0.978 & Not Supported \\
H3: $A \rightarrow$ JC & 0.257 & 0.058 & 4.394 & $0.000^{*}$ & Supported \\
H4: $\mathrm{N} \rightarrow$ JC & -0.053 & 0.040 & 1.329 & 0.184 & Not supported \\
H5: $\mathrm{E} \rightarrow$ JC & 0.349 & 0.061 & 5.685 & $0.000^{*}$ & Supported \\
\hline Note: $*$ p $<0.05$ & & & & &
\end{tabular}

\section{Conclusion and Managerial Implication}

This study aimed to examine the effects of Big Five personality traits on job crafting. Based on the academic staff of Malaysian private universities, extraversion has a significant effect on job crafting and has been supported. In fact, this study has revealed that the aforementioned quality is the strongest predictor of job crafting, thereby supporting hypothesis H5. Similarly, Barrick et al. (2001) as well as Bono and Judge (2004) have reported that extraverts are more energetic and actionoriented than introverts. They also talked more than they listened, worked well in teams and actively 
INTERNATIONAL JOURNAL OF ACADEMIC RESEARCH IN BUSINESS AND SOCIAL SCIENCES Vol. 10, No. 7, July, 2020, E-ISSN: 2222-6990 @ 2020 HRMARS

participated in social interactions in their daily life. Drawing on this reason, extraverts were more likely to take initiatives to craft their jobs, thereby fulfilling their daily needs, modifying their methods of interaction and adapting to the environment.

In the meantime, openness to experience was shown to have a significant and positive effect on job crating, and H1 was supported. Similarly, Lyons (2008), Tims et al. (2012), as well as Bell and Njoli (2016) had reported that apart from being inventive, employees with high openness to experience scores were more likely to seek others' feedback, new opportunities, novel experiences and additional knowledge. Given the associations of openness and willingness to adopt new things with experience, it could be concluded that employees who exhibited such values were more likely to engage in job crafting.

The relationship between agreeableness and job crafting was significant, and H3 was supported. In a similar manner, Illies et al. (2009), Mehmetoglu (2012) and Barrick et al. (2013) had proven that agreeable employees were more altruistic, helpful, kind, likeable and tender-minded. Altruism entails the concepts of selflessness and willingness to perform tasks that bring forth benefits to colleagues or co-workers. Moreover, helpful and likeable employees probably have a stronger desire to support their colleagues in order to foster good interpersonal relationships. An academic staff might be a colleague or co-worker with their counterparts of the same institution or other universities. Hence, it could be concluded that agreeable staffs were more likely to modify their jobs or work efforts to different tasks since they intended to get along with other academicians as well as complete research projects and teaching jobs.

Meanwhile, conscientiousness and neuroticism had no significant effect on job crafting, hence $\mathrm{H} 2$ and $\mathrm{H} 4$ were not supported. This finding was in line with literatures which had found that conscientiousness had no significant and direct effect on job crafting (Bell \& Murugan, 2013; Schaufeli, 2013; Tims et al., 2013). Instead of improvisations, highly conscientious employees are less spontaneous and prefer order and well-articulated action plans as these work ethics have been imbued in them at an early age. Furthermore, these highly self-disciplined and persistent employees often conform to regulations and avoid changes in their job characteristics. For this reason, it was not surprising that conscientiousness did not have a significant effect on job crafting. Moreover, academic staff who had high scores in this dimension also did not craft their jobs. Also, neurotic employees tended to be more sensitive and anxious, apart from frequently exhibiting negative emotion such as fear (Shiraev, 2016). Evidently, this finding contradicted those of Bosnjak, Galesic and Tuten (2007), Marta and Bakker (2016), as well as Bell and Njoli (2016), where neurotic workers were more likely to experience personal insecurity and perceived ordinary tasks to be difficult. Hence, in order to overcome the aforementioned emotional weaknesses, these employees resorted to job crafting. In view of the inadequacy of past researches on the link between neuroticism and job crafting, the finding of this study has contributed to the literature in the context of private education. In light of the importance of personality tests in the augmentation of job crafting behaviours, the top management of universities has to fully understand the connections between personality traits and job crafting. Therefore, it is advocated that Malaysian private universities provide funding to expert groups for the conducting of comprehensive university-based studies. By doing so, more accurate personality identification guidelines can be devised, which in turn promote proactivity and work performance.

The study's findings contribute to the existing literature in a number of ways. Firstly, insufficient past empirical findings are the main problem in testing the relationship of the Big Five personality traits 
and job crafting among the academic staff in Malaysian private universities. It is believed that this study is able to provide some forms of empirical data and to contribute to prior theories by examining how the Big Five personality traits affect job crafting in the Malaysian context. This reveals that the individual's personality can be beneficial in the strategic human resource practices in the aspect of promoting job crafting behaviour. Secondly, this study therefore also unveils the most influential dimensions of the individual's personality (e.g. extraversion) that determine the behaviour of job crafting, thereby providing guidelines for private universities in the implementation of the appropriate practices and training in order to improve the work quality and to stimulate more academic staff engagement.

\section{Limitations and Recommendations for Future Research}

Although this study has contributed significantly to the body of knowledge on the antecedents of job crafting, the results cannot be generalised. Additional researches are required to further investigate the relationship between personality and job crafting. Future research should employ better approaches, such as the improvement of the data collection process to cover a wider geographical area. Finally, longitudinal approaches should be adopted by future researchers as the respondents' behaviours and attitudes may change with time (Gratton \& Jones, 2004).

\section{References}

Andersson, S., \& Pears, A. N. (2017). The impact of academic staff development on their approach to teaching and learning. In ASEE Annual Symposium.

Bakker, A. B., Tims, M., \& Derks, D. (2012). Proactive personality and job performance: The role of job crafting and work engagement. Human Relations, 65(10), 1359-1378.

Barrick, M. R., Mount, M. K., \& Li, N. (2013). The theory of purposeful work behaviour: The role of personality, higher-order goals, and job characteristics. Academy of Management Review, 38(1), 132-153.

Barrick, M. R., Mount, M. K., \& Judge, T. A. (2001). Personality and performance at the beginning of the new millennium: What do we know and where do we go next? International Journal of Selection and Assessment, 9(1-2), 9-30.

Barclay, D., Higgins, C., \& Thompson, R. (1995). The partial least squares (PLS) approach to causal modelling: Personal computer adoption and use as an illustration. Technology Studies, 2(2), 285-309.

Bell, C., \& Njoli, N. (2016). The role of Big Five factors on predicting job crafting propensities amongst administrative employees in a South African tertiary institution. SA Journal of Human Resource Management, 14(1), 1-11.

Bell, C., \& Murugan, C. (2013). The relationship between conscientiousness, extraversion and leadership effectiveness among local government managers in Eastern Cape, South Africa. African Journal of Business Management, 7(43), 4386- 4397.

Bono, J. E., \& Judge, T. A. (2004). Personality and transformational and transactional leadership: A meta-analysis. Journal of Applied Psychology, 89(5), 901-910.

Bosnjak, M., Galesic, M., \& Tuten, T. L. (2007). Personality determinants of online shopping: Explaining online purchase intentions using a hierarchal approach. Journal of Business Research, 60(6), 597-605. 
INTERNATIONAL JOURNAL OF ACADEMIC RESEARCH IN BUSINESS AND SOCIAL SCIENCES

Vol. 10, No. 7, July, 2020, E-ISSN: 2222-6990 @ 2020 HRMARS

Chiaburu, D. S., Oh, I., Berry, C. M., Li, N., \& Gardner, R. (2011). The five-factor model of personality traits and organisational citizenship behaviours: A meta-analysis. Journal of Applied Psychology, 96(6), 1140-1166.

Chinelato, R. S. D. C., Ferreira, M. C., \& Valentini, F. (2015). Evidence of validity of the job crafting behaviours scale. Paideia, 25(62), 325-332.

Costa, P. T., \& McCrae, R. R. (1995). Domains and facets: Hierarchical personality assessment using the revised NEO personality inventory. Journal of Personality Assessment, 64(1), 21-50.

Da Wan, C., Sirat, M., \& Razak, D. A. (2015). The idea of a university: Rethinking the Malaysian context. Humanities, 4(3), 266-282.

Digman, J. M. (1990). Personality structure: Emergence of the five-factor model. Annual Review of Psychology, 41(1), 417-440.

Donnellan, M. B., Oswald, F. L., Baird, B. M., \& Lucas, R. E. (2006). The Mini-IPIP scales: Tiny-yeteffective measures of the big five factors of personality. Psychological Assessment, 18(2), 192203.

Eysenck, H. J., \& Eysenck, S. B. G. (1994). Manual for the Eysenck personality questionnaire (EPQ-R Adult). San Diego, CA: Educational Industrial Testing Service.

Fornell, C. R., \& Larcker, D. F. (1981). Structural equation models with unobservable variables and measurement error. Journal of Marketing Research, 18(3), 328-388.

Gratton, C., \& Jones, I. (2004). Research methods for sports studies. London: Routledge.

Hair, J. F., Hult, G. T. M., Ringle, C. M., \& Sarstedt, M. (2017). A Primer on Partial Least Squares Structural Equation Modeling (PLS-SEM). Thousand Oaks, CA: Sage.

Hair, J. F., Ringle, C. M., \& Sarstedt, M. (2011). PLS-SEM: Indeed a silver bullet. Journal of Marketing Theory and Practice, 19(2), 139-152.

Harari, M. B., Jain, N. K., \& Joseph, T. (2014). The Five-factor Model of personality and knowledge transfer in the United Arab Emirates. International Journal of Selection and Assessment, 22(4), 399-410.

Hogan, J., \& Holland, B. (2003). Using theory to evaluate personality and job-performance relations: A socio-analytic perspective. Journal of Applied Psychology, 88(1), 100-112.

Ilies, R., Fulmer, I. S., Spitzmuller, M., \& Johnson, M. D. (2009). Personality and citizenship behaviour: The mediating role of job satisfaction. Journal of Applied Psychology, 94(4), 945-959.

Van Rensburg, J. Y., Boonzaier, M., \& Boonzaier, B. (2013). The job demands-resources model of work engagement in South African call centres. SA Journal of Human Resource Management, 11(1), 1-13.

Kamarudin, S. K., Abdullah, S. R. S., Kofli, N. T., Rahman, N. A., Tasirin, S. M., Jahim, J., \& Rahman, R. A. (2012). Communication and teamwork skills in student learning process in the university. Procedia - Social and Behavioral Sciences, 60, 472- 478.

Lai, C. L., \& Hamdam, A. R. (2014). Secondary school teachers' effective teaching practice. Journal of Education and Practice, 5, 127-132.

Lyons, P. (2008). The crafting of jobs and individual differences. Journal of Business Psychology, 23(12), 25-36.

Marta, R., \& Bakker, A. B. (2016). Who seeks job resources, and who avoids job demands? The link between dark personality traits and job crafting. The Journal of Psychology, 150(8), 1026-1045.

Mehmetoglu, M. (2012). Personality effects on experiential consumption. Personality and Individual Differences, 52(1), 94-99. 
INTERNATIONAL JOURNAL OF ACADEMIC RESEARCH IN BUSINESS AND SOCIAL SCIENCES

Vol. 10, No. 7, July, 2020, E-ISSN: 2222-6990 @ 2020 HRMARS

Morton, N., Hill, C., \& Meiring, D. (2018). Validating the South African personality inventory (SAPI): Examining green behaviour and job crafting within a nomological network of personality. International Journal of Personality Psychology, 4(1), 25-38.

Musa, K., \& Abd Halim, H. (2015). Kemahiran interpersonal guru dan hubungan dengan pencapaian akademik pelajar (Interpersonal teacher skill and it's relationship with students' academic achievement). Jurnal Pendidikan Malaysia (Malaysian Journal of Education), 40(2), 89-99.

Noordin, F., \& Jusoff, K. (2009). Levels of job satisfaction amongst Malaysian academic staff. Asian Social Science, 5(5), 122-128.

Oerlemans, W. G. M., \& Bakker, A. B. (2014). Why extraverts are happier: A day reconstruction study. Journal of Research in Personality, 50(1), 11-22.

Ono, M., Sachau, D. A., Deal, W. P., Englert, D. R., \& Taylor, M. D. (2011). Cognitive ability, emotional intelligence, and the Big Five personality dimensions as predictors of criminal investigator performance. Criminal Justice and Behaviour, 38(5), 473.

Peral, S. L., \& Geldenhuys, M. (2020). The indirect relationship between personality and performance through job crafting behaviour. SA Journal of Industrial Psychology, 46(1), 1-12.

Sarstedt, M., Ringle, C. M., Smith, D., Reams, R., \& Hair, J. F. (2014). Partial least squares structural equation modeling (PLS-SEM): A useful tool for family business researchers. Journal of Family Business Strategy, 5(1), 105-115.

Schaufeli, W. B. (2013). What is engagement. Employee Engagement in Theory and Practice, 15, 321.

Schneider, T. R. (2004). The role of neuroticism on psychological and physiological stress responses. Journal of Experimental Social Psychology, 40(6), 795-804.

Shiraev, E. (2016). Personality theories: A global view. USA: Sage.

Sterns, L., Alexander, R. A., Barrett, G. V., \& Dambrot, F. H. (1983). The relationship of extra version and neuroticism with job preferences and job satisfaction for clerical employees. Journal of Occupational Psychology, 56(2), 145-153.

Sung, Y. T., Chang, K. E., Liu, T. C. (2016). The effects of integrating mobile devices with teaching and learning on students' learning performance: A meta-analysis and research synthesis. Computers and Education, 94, 252-275.

Tims, M., Bakker, A. B., \& Derks, D. (2012). Development and validation of the job crafting scale. Journal of Vocational Behaviour, 80(1), 173-186.

Tims, M., Bakker, A. B., \& Derks, D. (2013). The impact of job crafting on job demands, job resources, and well-being. Journal of Occupational Health Psychology, 18(2), 230-240.

Van Wingerden, J., Bakker, A. B., \& Derks, D. (2017). The longitudinal impact of a job crafting intervention. European Journal of Work and Organizational Psychology, 26(1), 107-119.

Wiggins, J. S., \& Trapnell, P. D. (1997). Personality structure: The return of the Big Five. In Handbook of personality psychology (pp. 737-765). Academic Press.

Wrzesniewski, A., \& Dutton, J. E. (2001). Crafting a job: Revisioning employees as active crafters of their work. Academy of Management Review, 26, 179-201.

Wrzesniewski, A., LoBuglio, N., Dutton, J. E., \& Berg, J. M. (2013). Job crafting and cultivating positive meaning and identity in work. Advances in Positive Organizational Psychology, 1, 281-302.

Zhang, X. C., Kuchinke, L., Woud, M. L., Velten, J., \& Margraf, J. (2017). Survey method matters: Online/offline questionnaires and face-to-face or telephone interviews differ. Computers in Human Behaviour, 71, 172-180. 
INTERNATIONAL JOURNAL OF ACADEMIC RESEARCH IN BUSINESS AND SOCIAL SCIENCES

Vol. 10, No. 7, July, 2020, E-ISSN: 2222-6990 @ 2020 HRMARS

Zhu, Z., Sun, Y., \& Riezebos, P. (2016). Introducing the smart education framework: Core elements for successful learning in a digital world. International Journal of Smart Technology and Learning, 1(1), 53-65.

Zikmund, W. G., Babin, B. J., Carr, J. C., \& Griffin, M. (2010). Business research methods. South Western, Canada: Cengage Learning. 